\title{
ZONATION OF CONSERVATION PRIORITY SITES FOR EFFECTIVE MANAGEMENT OF TROPICAL FORESTS IN INDIA: A VALUE-BASED CONSERVATION APPROACH
}

\author{
S. SOOSAIRAJ ${ }^{1 *}-$ S. JOHN BRITTO ${ }^{2}$ - B. BALAGURU ${ }^{3}-$ N. NAGAMURUGAN ${ }^{4}-$ D. NATARAJAN ${ }^{2}$ \\ ${ }^{\text {I} D e p a r t m e n t ~ o f ~ B o t a n y, ~ S t . J o s e p h ' s ~ C o l l e g e ~(A u t o n o m o u s), ~}$ \\ Tiruchirappalli, 620 002, Tamil Nadu, India \\ ${ }^{2}$ Rapinat Herbarium, St.Joseph's College (Autonomous), Tiruchirappalli, 620002 \\ ${ }^{3}$ Research Associate, National Innovation Foundation, Ahmedabad, India \\ ${ }^{4}$ Department of Biotechnology, Kurinji College of Arts and Science, Tiruchirappalli, 620002 \\ e-mail:pspsoosai@yahoo.co.in
}

(Received $5^{\text {th }}$ April 2006; accepted $10^{\text {th }}$ April 2007)

\begin{abstract}
Zonation of conservation sites has been modelled by overlaying different layers such as vegetation type, species richness, endangered, endemic, economic status maps and socio-cultural value map using remote sensing and GIS in the Pacchaimalai hills part of Eastern Ghats in India that is spread to an area of $527.61 \mathrm{sq} . \mathrm{km}$. These hills are situated at the mid regions of Tamil Nadu with latitudes $11^{\circ} 09^{\prime} 00^{\prime \prime}$ to $11^{\circ} 27^{\prime} 00^{\prime \prime} \mathrm{N}$ and longitudes $78^{\circ} 28^{\prime} 00^{\prime \prime}$ to $78^{\circ} 49^{\prime} 00^{\prime \prime} \mathrm{E}$. They harbour eight vegetation types of which tropical dry deciduous forests are widespread with rich diversity. As in other hills, the forest cover is under severe anthropogenic pressure in spite of being protected as a reserved forest. This study proposes about $0.93 \%$ (4.95 sq. $\mathrm{km}$ ) of the total area of the Pacchaimalai hills for immediate conservation. The effectiveness of the proposal would be based on the attitude and awareness of local people towards vegetation who inhabit the areas adjacent to proposed sites and the effective monitoring by foresters and participatory approach of both the people and forest authorities to accomplish the goal of the conservation of biodiversity and sustainable use of natural resources. Keywords: conservation, remote sensing, geographical information system, species richness, Margalef index
\end{abstract}

\section{Introduction}

Formal protection of natural resources in reserves has tended to be ad hoc favouring the biodiversity of areas that are least valuable for commercial use, in public tenure but earnest to reserve, most charismatic, and with least need for protection $[19,11]$ which is quite sentimental to protection strategy. Therefore methods for identifying priority areas are only one aspect of overall biological conservation planning and management [10, 4]. In Indian context ecosystems are rich in natural resources, but are under constant stress and exploitation [7]. Due to this heavy pressure, India has lost $7,422 \mathrm{~km}^{2}$ forests during the intervening period between 1987 and 1999 assessment [18]. This fact reminds us that the rate of biodiversity loss is more in tropical countries like India especially in the regions of Eastern Ghats, a rugged hilly terrain running almost parallel to the eastern coast of India, characterized by the broken hills with its small patches of vegetation with manmade plantations and habitations. Stresses on this adjoining biota are increasing due to easy accessibility in the pertinent. Even after decades of superficial establishment of protected areas in these hills there is a negligible difference in deforestation rates inside and outside protected areas. This study focuses on a segment of Eastern Ghats i.e. 
Pacchaimalai hills, which includes vegetation types such as Dry evergreen, Dry mixed deciduous, Savannah and grasslands. The hills are most significant socio-culturally because most of the forest patches are regarded as sacred groves (vestiges of habitation reserved for deity as in abode). These hills have been studied earlier mainly for the floristic analysis [12], besides this there is no significant developmental studies such as biodiversity and conservation. Though it is ideal to protect all places that contribute to biodiversity conservation, it is high cost and time consuming. Developing countries like India could not afford to spend on such a heavy task. Current protected areas contain relatively few biodiversity surrogates or those that are not in most urgent protection and there is very uneven representation of biodiversity in existing protected areas. Thus scoring and ranking procedures were developed as an attempt to make systematic priority setting effectively explicit [25, 26]. Thus the present study focuses on identification of conservation priority sites based on the scoring and ranking procedures. Our objectives include the estimation of the exhaustive knowledge of species diversity and distribution and the zonation of conservation values sites in the existing reserve areas and ranking the conservation priority sites.

\section{Review of literature}

There are many methods used for priority settings such as scoring and ranking procedures [11]. Two types of information are necessary for setting conservation priorities; the conservation value of an area and its vulnerability [13]. These pieces of information should include multiple criteria such as vegetation type [33], species richness [22], socio-economic and socio-cultural value sites [21], endemism [6], concentration of red listed plants [8, 1] and stresses on the biota [28]. Few vegetation types, though they are less important, should maintain the ecological balances, for the representativeness [23] and such vegetation types should also be included on the conservation priority sites. Each criterion is assigned with weight and then the scores are combined for each candidate area. The areas are then ranked accordingly and highest priority is given to the areas with the highest scores. Nevertheless there had been many critical reviews of these procedures and the criteria used [11].

\section{Materials and methods}

\section{Study area}

The Pacchaimalai hills are situated at the central region of Tamil Nadu, India, with latitudes $11^{\circ} 09^{\prime} 00^{\prime \prime}$ to $11^{\circ} 27^{\prime} 00^{\prime \prime} \mathrm{N}$ and longitudes of $78^{\circ} 28^{\prime} 00^{\prime}$ ' to $78^{\circ} 49^{\prime} 00^{\prime \prime} \mathrm{E}$ (Map 1). They occupy an area of about $527.61 \mathrm{sq} . \mathrm{km}$ and altitudes range of 160 to $1072 \mathrm{~m} \mathrm{msl}$. The vegetated area is distributed into 35 reserved forests. The Pacchaimalai hills enjoy a sub-tropical climate with temperatures varying from $25^{\circ} \mathrm{C}$ to $31^{\circ} \mathrm{C}$ and annual rainfall ranging from 800 to $900 \mathrm{~mm}$. The total tribal population is around 12,000 who live in 70 hamlets scattered all over the plateau area. The area is underlain by the crystalline rocks of the Archaean age comprising gneisses, charnockites and granites with little soil cover i.e., red loamy and black. The alluvium is found in narrow patches along the river courses and is restricted in thickets. The crystalline terrain exhibits multi spectral and poly metamorphic complexity. Dominant

plant species of these areas are Nothopegia colebrookiana, Aglaia elaegnoidea, 
Cipadessa baccifera, Diospyros ferrea, Glycosmis mauritiana. Tarenna asiatica. Carissa carandas, Chloroxylon swietenia, Albizia amara, Commiphora caudata, Commiphora berryi, Pterolobium hexapetalum and Celtis philippensis. A few important species are Santalum album, Cycas circinalis and Canarium strictum. The Pacchaimalai harbour spotted deer, Hyenas, Sloth bear and Monkey like animals.

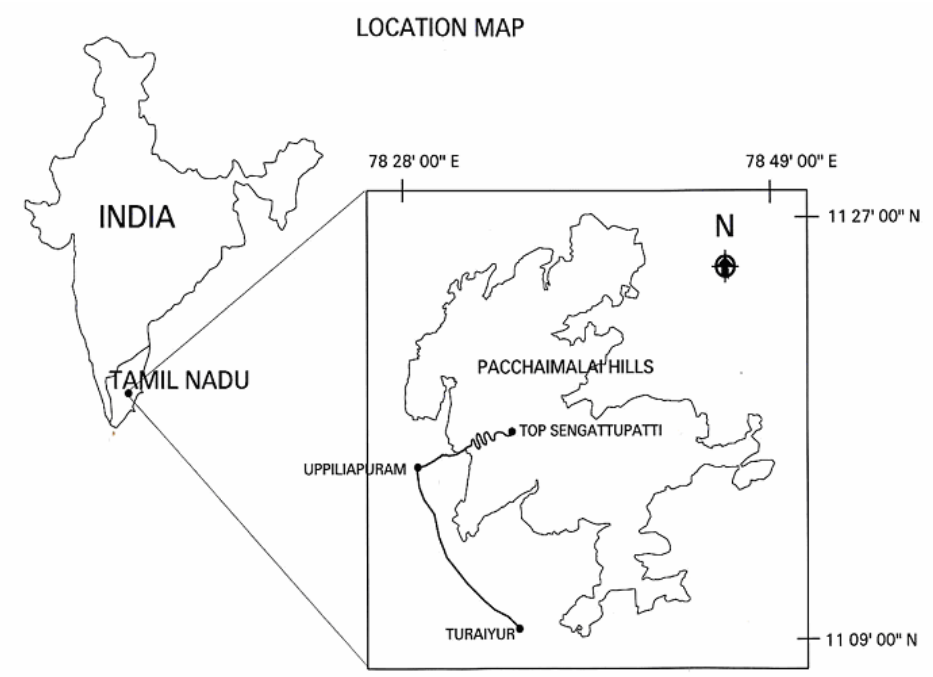

Map 1. Location map of Pacchaimali. Eastern Ghats of Tamil Nadu, India

\section{Data generation}

\section{Mapping vegetation map}

Vegetation type map (Forest type) of Pacchaimalai hills [27] cover 73.95\% (390200 ha.) under reserved forests comprising about nine major forest types i.e., evergreen, semi evergreen, dry mixed deciduous, southern thorn scrub, dry savannah, southern thorn forest and dry grass land (Map 2).
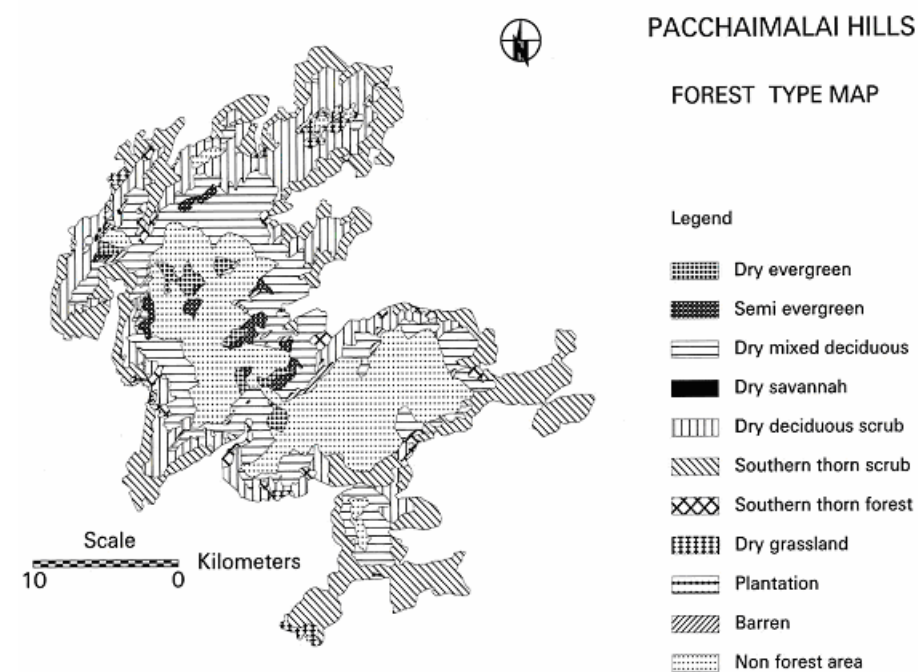

Map 2. Forest types of Pacchaimalai Hills

APPLIED ECOLOGY AND ENVIRONMENTAL RESEARCH 5(2): 37-48.

http://www.ecology.uni-corvinus.hu • ISSN 15891623

(C) 2007, Penkala Bt., Budapest, Hungary 
The level of biological similarity of a particular site with other similar sites or with an ecosystem type in terms of the number and percentage of defining characteristics would determine its representativeness [23]. Since it is impossible to locate a site that represents an entire ecosystem, sites can be prioritized on the basis of levels of similarity. To evolve potential conservation strategy various elements are used as base for conservation priority, whereas the dry deciduous scrub and southern thorn scrub forests are excluded, as they are highly degraded forms of dry mixed deciduous forests.

\section{Generation of species data base}

This includes the preparation of floristic species richness, red list, endemism and economic value map. All the maps were prepared using the vegetation types with the ground data. For species richness map, sampling quadrates with the size $20 \mathrm{~m}$ x $20 \mathrm{~m}$ were laid in each vegetation type and frequency and number of all vascular plant species were collected in each quadrates and later utilized to estimate Margalef richness index [9] (Eq. 1).

$$
\operatorname{Dmg}=\mathrm{S}-1 / \log \mathrm{N}
$$

Where $\mathrm{S}$ - is number of species recorded, $\mathrm{N}$ - total number of individual of all the species; In - $\log _{\mathrm{e}}$. Each polygon of the respective vegetation type was replaced by Margalef diversity index and species richness values of all polygons were classified under three classes, i.e. low, medium, high.

Mapping of the Red listed and Endemic species (Table 1) is normally done based on the data collected from the above described quadrates and cross checked with the appropriate literature. Weights were attributed based on the summation of species under endemism and Red listed category [15] and again regrouped into three categories.

For preparation of economic value map, the economic values (i.e., medicinal (5), edible (2) and others (fuel -2, fodder-2 and timber-2) of each species that is encountered in each quadrate were summed and the summed values were attributed to the respective polygons as described above to reclassify similar valued polygons to form the final economic value map.

Table 1. List of plant species and their status

\begin{tabular}{|l|c|c|}
\hline \multicolumn{1}{|c|}{ Name of species } & Status & Value \\
\hline Alstonia scholaris (L.) R.Br. & $\mathrm{V}$ & 2 \\
\hline Andrographis lineata Wallich ex Nees & $\mathrm{E}$ & 5 \\
\hline Aphanamixis polystachya (Wall.) Parker & $\mathrm{V}$ & 4 \\
\hline Asystasia crispata Benth. & $\mathrm{E}$ & 5 \\
\hline Balanophora fungosa Forster and Forster & $\mathrm{E}$ & 5 \\
\hline Barleria acuminata Nees & $\mathrm{E}$ & 5 \\
\hline Barleria longiflora L.f. & $\mathrm{E}$ & 5 \\
\hline Bridelia crenulata Roxb. & $\mathrm{E}$ & 5 \\
\hline Canarium strictum Roxb. & $\mathrm{V}$ & 4 \\
\hline Canavalia cathartica Thouars & $\mathrm{R}$ & 1 \\
\hline Cayratia pedata (Lour.) A. J. Juss. ex Gagnepain & $\mathrm{En}$ & 5 \\
\hline Celastrus paniculatus Willd. & $\mathrm{V}$ & 4 \\
\hline Ceropegia juncea Roxb. & $\mathrm{E}$ & 5 \\
\hline Cinnamomum macrocarpum auct. non Hook.f. & $\mathrm{R}$ & 1 \\
\hline Crotalaria medicaginea Lam. & $\mathrm{R}$ & 1 \\
\hline Curcuma neilgherrensis Wight & $\mathrm{E}$ & 5 \\
\hline Cycas circinalis L. & $\mathrm{T}$ & 2 \\
\hline
\end{tabular}

APPLIED ECOLOGY AND ENVIRONMENTAL RESEARCH 5(2): 37-48. http://www.ecology.uni-corvinus.hu • ISSN 15891623 (C) 2007, Penkala Bt., Budapest, Hungary 


\begin{tabular}{|c|c|c|}
\hline Name of species & Status & Value \\
\hline Elaeagnus indica Servettaz & $\mathrm{E}$ & 5 \\
\hline Embelia tseriam cottam (Roemer \& Schult.) A. DC. & V & 4 \\
\hline Gloriosa superba L. & En & 5 \\
\hline Gnetum edule (Willd.) Blume & En & 5 \\
\hline Gymnema elegans Wight \& Arn. ex Wight & $\mathrm{R}$ & 1 \\
\hline Habenaria heyneana Lindley & En & 5 \\
\hline Hemidesmus indicus (L.) R.Br. & $\mathrm{E}$ & 5 \\
\hline Mallotus stenanthus Muell. Arg. & $\mathrm{E}$ & 5 \\
\hline Miliusa eriocarpa Dunn & $\mathrm{E}$ & 5 \\
\hline Moringa concanensis Nimmo ex Dalz. \& Gibson & $\mathrm{V}$ & 4 \\
\hline Mucuna pruriens (L.) DC. & $\mathrm{E}$ & 5 \\
\hline Naravelia zeylanica (L.) DC. & $\mathrm{V}$ & 4 \\
\hline Ochna obtusata DC. & $\mathrm{R}$ & 1 \\
\hline Peperomia dindigulensis Miq. & $\mathrm{E}$ & 5 \\
\hline Pseudarthria viscida (L.) Wight \& Arn. & $\mathrm{L}$ & 3 \\
\hline Pterospermum xylocarpum (Gaertmer) Santapau \& Wagh & $\mathrm{T}$ & 2 \\
\hline Randia candolleana Wight \& Arn. & $\mathrm{E}$ & 5 \\
\hline Rubia cordifolia $\mathrm{L}$. & En & 5 \\
\hline Santalum album $\mathrm{L}$. & $\mathrm{T}$ & 2 \\
\hline Sapindus emarginata Vahl & $\mathrm{L}$ & 3 \\
\hline Smilax zeylanica $\mathrm{L}$. & $\mathrm{T}$ & 2 \\
\hline Stephania japonica (Thunb.) Miers & $\mathrm{V}$ & 4 \\
\hline Terminalia arjuna (DC.) Wight \& Arn. & $\mathrm{L}$ & 3 \\
\hline Tetrastigma sulcatum (M. Lawson) Gamble & $\mathrm{E}$ & 5 \\
\hline
\end{tabular}

V-Vulnerable, E- Endemic to Peninsular India, R-Rare, En- Endanger, T-Threatened, L-Lower risk

\section{Deforestation risk zone}

The anthropogenic pressures are found to be high near the hamlets and road network (metalled, unmetalled and foot path) and it might create secondary and tertiary routes to and within the forest area thereby increasing accessibility and vulnerability of the forest stand in the proximity. One km buffer for the road network and hamlet is generated to form the biotic pressure map. In this study threat posing as risk from human activities too was included as one of the thematic layers for identifying conservation priority zone.

\section{Socio-cultural valuable sites}

Sacred groves are patches of forests dedicated to deities, which are not usually disturbed. There is a strong need to promote such indigenous practice based packages for further rejuvenation and revitalization and as means of biodiversity conservation. Such socio-culturally protected areas would have been more imperative if one could value biodiversity in terms of economic value, utility, culture and religion. Due to modern civilization timber extraction was encountered in these sacred groves. However the wood extraction is strictly prohibited in the vicinity of the deity. This map has been prepared in terms of distribution of sacred groves in the Pacchaimalai hills. Distribution of sacred groves in the study area is mapped using GPS reading collected from the field, satellite imagery and SOI toposheets. 


\section{GIS overlay analysis}

The components of various units from the themes of vegetation type, floristic richness, endemism and red lists with respective scores (Figure 1) are quite essential to develop conservation priority zones.

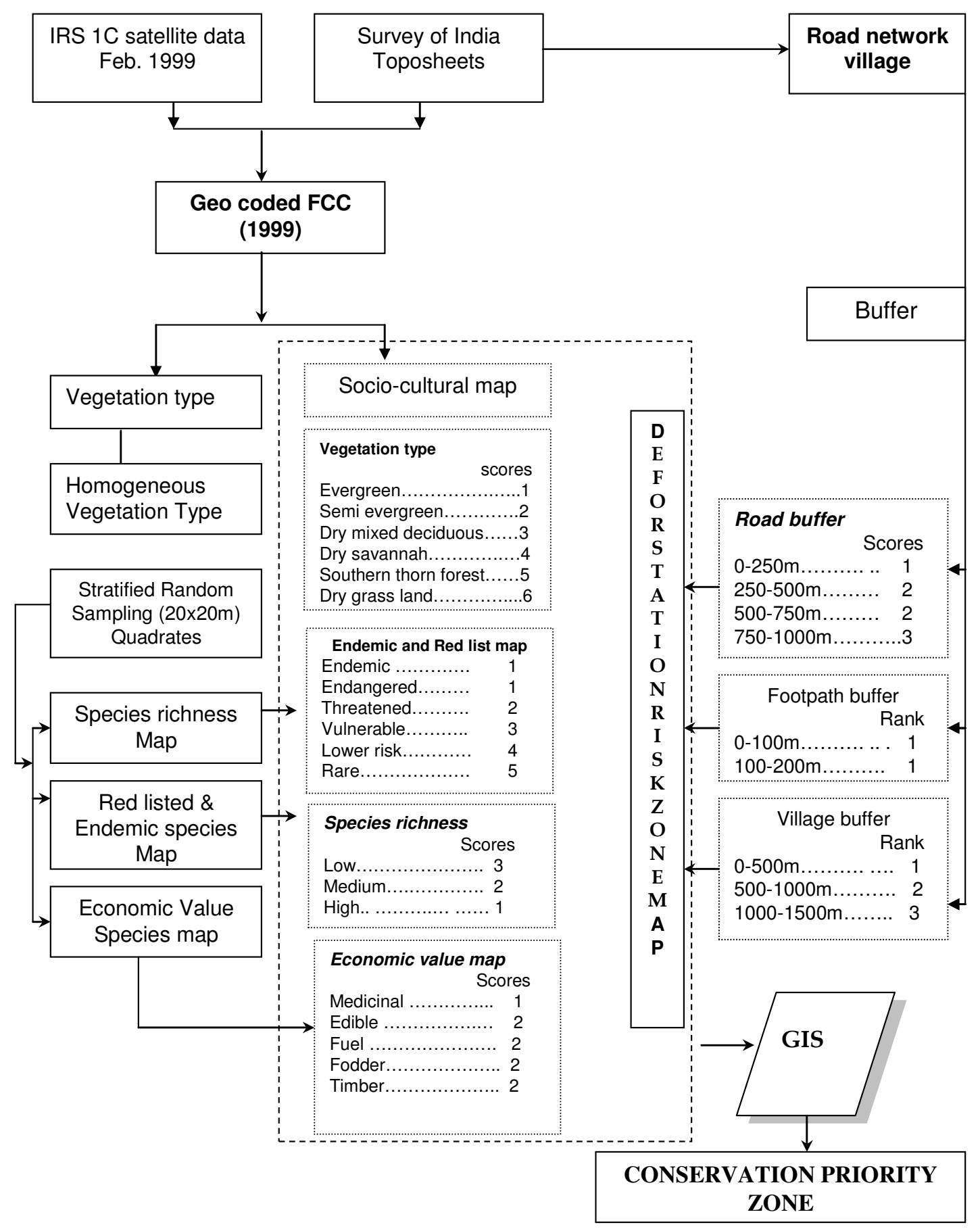

Figure 1. Conceptual diagram illustrating the building of Conservation Priority Zone 
Considering conservational importance and status for each unit of thematic layer, the weighting was designated to identify such Priority areas. Overlay or superimposition creates a composite output GIS file by combining a number of input GIS files based on the minimum or maximum values of the input files are summed [14]. These scores are then combined for each candidate area. The areas are then ranked and highest priority/rank is given to the areas with the highest scores. For preparation of conservation priority maps, thematic maps are overlaid on one another wherein the vegetation type forms the lowermost tier and other layers are superimposed in sequence i.e. species richness, red list and finally endemism map. The thematic maps are rasterized and coded using the Criteria function in ERDAS 8.3.1 and the product was used as bases for modelling in the software using yet another tool i.e., model maker wherein, the different features of the thematic layers were intersected/ extracted and new class values were attributed to them and finally integrated (union) according to above mentioned sequence and finally conservation priority zone (Map 3) was prepared. The resulting polygons were classed according to the priority status. The authenticity of the areas/zones proposed for conservation priority is confirmed with ground justification. The endemic, red listed and biotic pressure zone maps were stored as temporary raster layers and used during GIS overlay analysis.

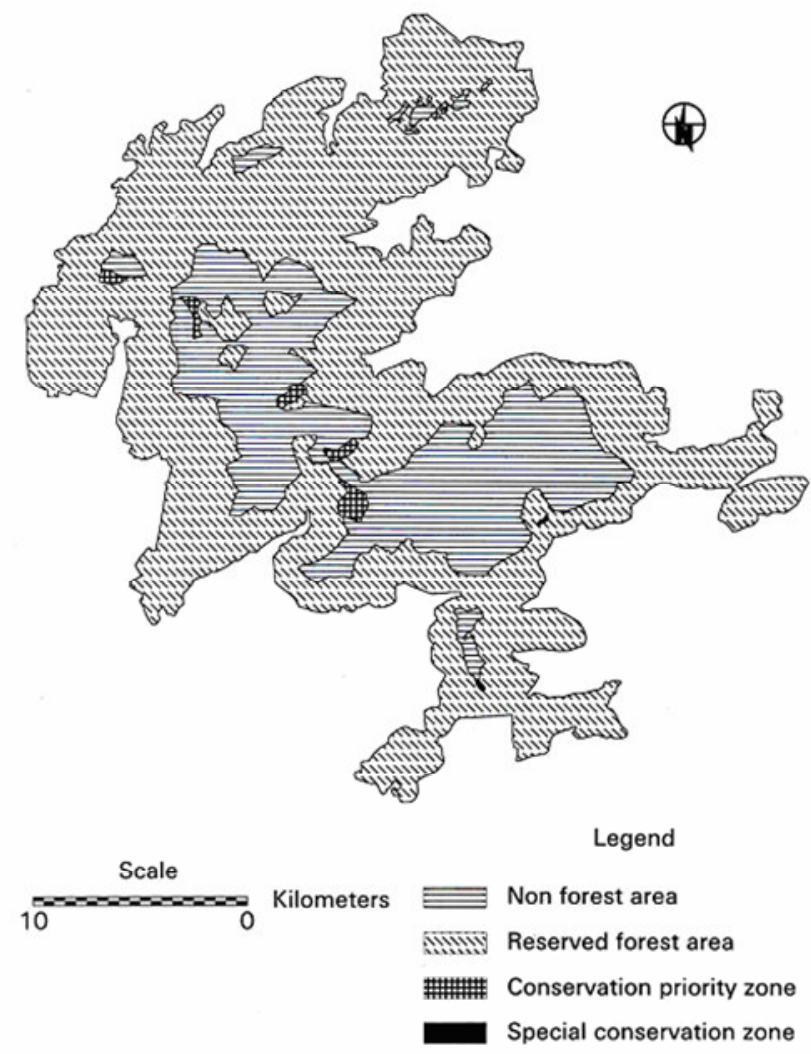

Map 3. Conservation Priority zone map of Pacchaimalai Hills 


\section{Results}

The priority area that has been modelled comprises $4.95 \mathrm{sq} . \mathrm{km}$, about $0.93 \%$ of the total hill area and is at five different localities. The site I has about 172.62 ha, and conspicuous for its rich diversity, and comprises a large number of endemic, endangered and vulnerable species. The slope is gentle to moderate. Huge woody liane like Gnetum edule, Aganosma cymosum, Symphorema involucratum and others inhabit the site. Tall trees growing up to $25-30 \mathrm{~m}$ are common, namely Syzygium cumini. Alstonia scholaris, Canarium strictum, Nothopegia colebrookiana and occasional presence of Cinnamomum macrocarpum, Aglaia eleagnoidea and Atrocarpus heterophylus are noteworthy. The villagers violating the ethos of sacred grove have noticed occasional grazing of cattle along the periphery, besides a few instances of encroachment. Proper fencing would surely help in conserving the rich natural resources.

Site II occupies an area of about 78.95 ha. and consists of trees growing up to $20 \mathrm{~m}$. Dominant tree species are Putranjiva roxburghii. Pterospermum xylocarpum, Chukrasia tabularis and Psydrax dicoccos. Large expanse of degraded areas surrounding this site is a clear evidence of the disturbance and fire wood collection from this site. Lianes such as Gnetum edule, Symphorema involucratum, Elaeagnus indica are frequent. Slope is moderate to steep. Ground vegetation is sparse owing to dense tree cover.

Site III with 86.85 ha has been suggested for conservation. The slope is moderate and the slope facing the north is conserved well due to the dwelling of Kaliamman deity, however the slope facing the south is drastically disturbed. Constituent tree species are Nothopegia colebrookiana, Scolopia crenata, Mimusops elengi, Psydrax dicoccos and Diospyros ovalifolia. Twiners like Clematis gouriana and Rubia cordifolia have been collected from this site. Frequent visits of cattle are encountered and occasional felling is noticed.

Area demarcated for conservation for the site $I V$ is 77.18 ha. The highest elevation point $1071 \mathrm{~m} \mathrm{msl}$ in the Pacchaimalai hills is located here and slope is moderate to steep. It is a sacred grove where in the stretches surrounding the area has been cleared, and the exotic tree Plumera rubra has been extensively planted. The forest is highly degraded due to casual cutting and felling thus leading to heavy run-off and subsequent erosion. Diospyros ovalifolia, Ochna obtusata, Nothopegia colebrookiana and Gymnema sylvestre have been recorded.

In the site $\mathrm{V}$ a big temple has been constructed in honour of the resident deity Perumal. The vegetation is dense and the common species are Memecylon edule, Nothopegia colebrookiana, Diospyros ovalifolia, Schleichera oleosa and Alseodaphne semecarpifolia that grow up to $10-15 \mathrm{~m}$ tall. Frequent grazing by cattle does occur besides cutting and felling. Curcuma neilgherrensis is found only at this site in the hills.

\section{Discussion}

The Pacchaimalai hills support many types of vegetation of this the dry evergreen forests have been considered significant due to their dense cover, besides their distinct composition. Evergreen forests are relatively common in the Western Ghats of Peninsular India; however, dry evergreen forests are meagre in distribution and are 
confined to higher elevations of the Eastern Ghats that are discontinuous and in small patches. Presence of such vegetation is an indication, that the lower elevation hills like the Eastern Ghats could harbour good vegetation and also they are the vestiges of the luxuriant vegetation cover of the past era in the Eastern Ghats, and hence needs to be protected. Species richness map (Map 4) refers to the number of species contained in an area and its measurement per unit area is perhaps the most objective of all the measures. Hence, it would be desirable to have a richness index independent of sample size. Vascular plant species richness has been used to characterize an ecosystem and that of biodiversity of an area [5, 30]. The species richness has been observed high not in completely covered or fully open vegetation rather, in partially degraded vegetation. Similar view has been also reported that the diversity of species tends to be greater in disturbed than undisturbed environment [24]. The dense cover area prevents the growth of herbaceous species while the open scrubland is unfit to harbour tree population.

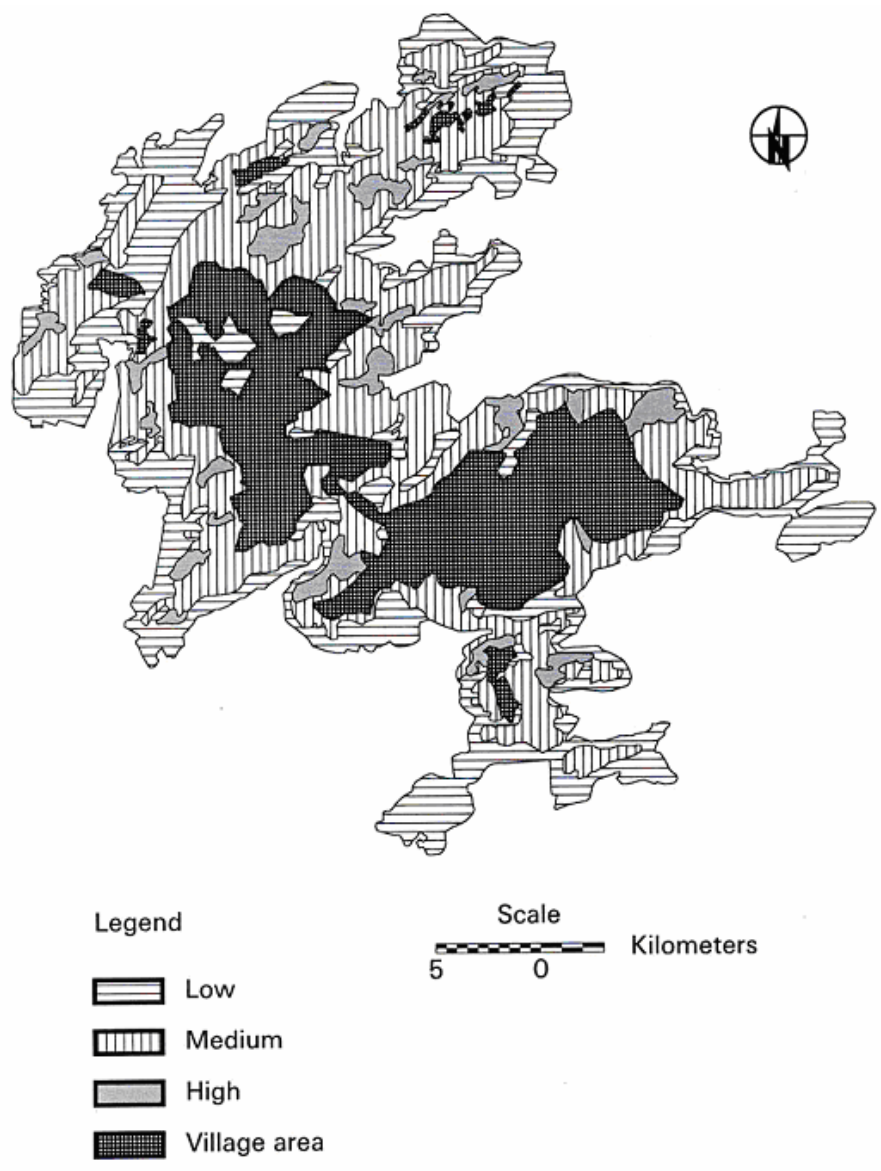

Map 4. Species richness map of Pacchaimalai Hills

Temporal patterning of disturbance plays an important role in determining species abundance and diversity [2]. The most widely published prioritization of species for conservation action has been the threatened species categories defined by the IUCN and used in its Red data book [8]. The species that are endangered, vulnerable, threatened and endemic requires prime importance in conservation measures $[20,16]$. There are 41 species under these criteria in the study area and tabulated herewith as endangered and 
endemic. The survival of these species, which have already reached critically low levels of population numbers, is dependent on certain critical factors of ecology, population dynamics or extrinsic factors such as exploitation and habitat loss or degradation. Hence, their distribution has been mapped (Map 5) in order to conserve them from extinction. Gloriosa superba, Cayratia pedata, Gnetum edule, Habenaria heyneana and Rubia cordifolia are the endangered species. Seventeen species are endemic to Peninsular India while eight species are vulnerable.

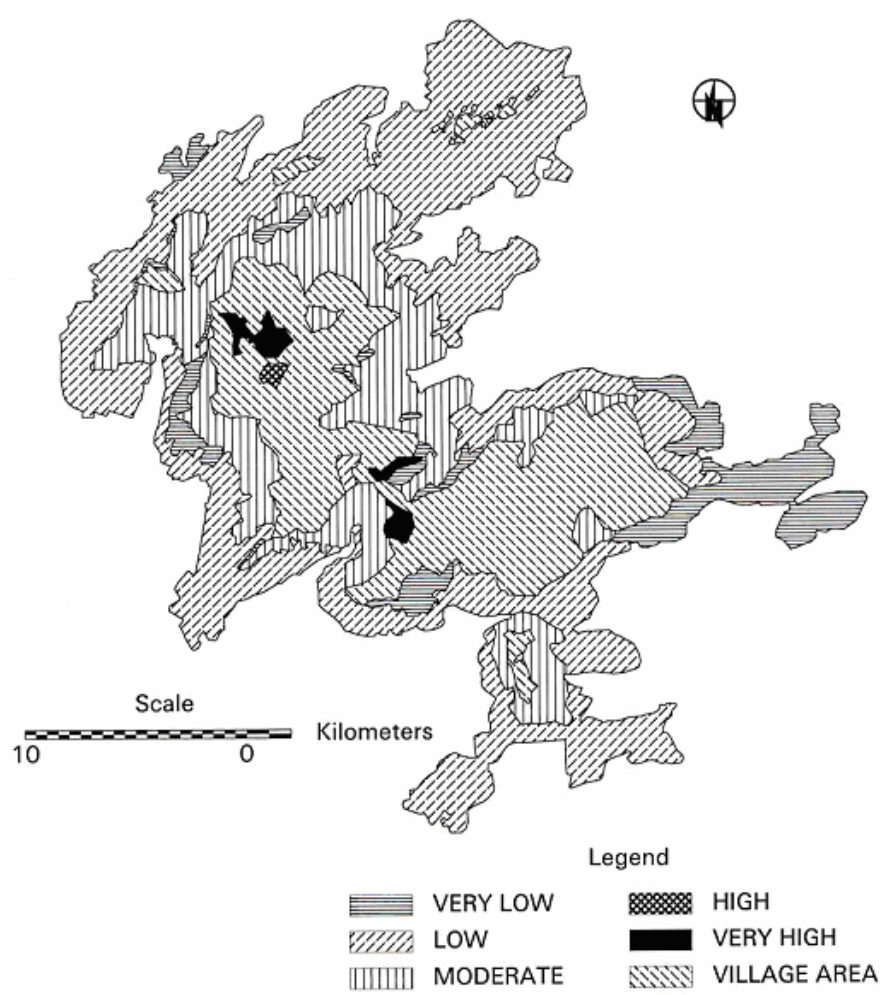

Map 5. Endangered/endemic species distribution value map of Pacchaimalai Hills

Association of trees with deities and demarcation of certain area as sacred are an ancient practice in India and other parts of the world. The associated tree and its surrounding habitat are revered and worshipped by people as sacred. The sacred groves that existed as conservation areas were now getting degraded and they needed to be studied and conservation strategies need to be prioritised for their preservation and perpetuation [21]. The sense of sanctity and the fear of the unknown, which helped their conservation, are gradually losing their hold. Hence, the task of conservation has assumed a greater urgency. In the Pacchaimalai hills, six groves are present namely Kannimar kovil, Kaliamman kovil, Masimalaian kovil, Perumal kovil (Kilkarai), Periya samy kovil (Periya shola) and Perumal kovil (Manmalai) and invariably all of these groves comprise dry evergreen vegetation in 848 ha and are repositories of a large number of rare and endemic plant species.

The forest loss and degradation are associated directly with proximity to roads and villages up to $6 \mathrm{Km}[13,29]$ that confirms the disturbing effect of roads by means of logging, mining, grazing, agriculture and urban development. Around 6500 ha of the reserved forest come into the risk area. This area would likely to increase if we include 
the footpath, which are numerous in the Pacchaimalai hills. The fuel wood consumption is calculated to be $2.4 \mathrm{Kg} /$ household / day [32]. Based on the 1991 census, the fuel wood requirement would be of the order 7.2 tones per day, which is likely to increase due to present growth rate of the population and the influence of the people who live surrounding the hills.

It is essential to consider the following three principles while selecting area for conservation and that an area should be efficient in capturing all the species and ecosystems [31]. This has become a difficult task since the sustenance requirement of each species differs considerably. Besides, different variables are considered as prerequisites for conservation of a species, for example the size of the protected area [3]. In addition to size, conditions and connectivity to maintain even the most sensitive species with the prevalent ecological processes are an essential foundation of any conservation strategy [17].

Acknowledgement: The authors wish to thank the MoEF, New Delhi for the financial assistance under project no. 23/10/94-RE and Tamil Nadu forest department and Tiruchirappalli Forest Division staff for the permission to carry out study in the Pacchaimalai hill forests.

\section{REFERENCES}

[1] Ahmedullah, M. (2000): Prioritisation of endangered plants of India. - In: Singh, S., Sastry, A.R.K., Mehta, R., Uppal, V. (eds.) Setting biodiversity priorities for India, 2: 442-459. - World Wide Fund for Nature, India, New Delhi.

[2] Armesto, J.J., Pickett, S.T.A. (1985): Experiments on disturbance in old-field plant communities: impact on species richness and abundance. - Ecol. 66: 230-240.

[3] Burgman, M.A., Possingham, H.P., Lynch, A.J.J., Keith, D.A., McCarthy, M.A., Hooper, S.K., Drury, W.L., Passioura, J.A., Devries, R.J. (2001): A method for setting the size of plant conservation target area. - Conserv. Biol. 15: 603-616.

[4] Gaston, K.J., Pressey, R.L., Margules, C.R. (2002): Persistence and vulnerability: retaining biodiversity in the landscape and in protected areas. - J. Biosci. 27: 361-384.

[5] Hooper, D.U., Vitousek, P.M. (1997): The effects of plant composition and diversity on ecosystem processes. - Sci. 277: 1302-1305.

[6] Kier, G., Barthlott, W. (2001): Measuring and mapping endemism and species richness: a new methodological approach and its application on the flora of Africa. - Biodiv. Conserv. 10: 1513-1529.

[7] Kumar, A. (2000): A decade of JFM in Inida: Looking back for better foresight. - Ind. Fores. 126: 579-582.

[8] Kumar, A., Walker, S., Molur, S. (2000): Prioritisation of endangered species. - In: Singh, S., Sastry, A.R.K., Mehta, R., Uppal, V. (eds.) Setting biodiversity priorities for India - World Wide Fund for Nature, India, New Delhi. pp. 341-386.

[9] Margalef, R. (1958): Information theory in ecology. - Gen. Syst. 3: 36-71.

[10] Margules, C.R., Pressey, R.L. (2000): Systematic conservation. - Nature (London) 405: 243-253.

[11] Margules, C.R., Pressey P.L., Williams, P.H. (2002): Representing biodiversity: Data and procedures for identifying priority areas for conservation. - J. Biosci. 27(4): 309-326.

[12] Matthew, K.M. (1983): The flora of the Tamil Nadu Carnatic. - Rapinat Herbarium Tiruchirappalli, Tamil Nadu, India.

[13] Menon, S., Gil Pontius, J.R.R., Rose, J., Khan, M.L., Bawa, K.S. (2001): Identifying conservation priority areas in the tropics: a landuse change modeling approach. Conserv. Biol. 15: 501-512. 
[14] Murthy, K.S.R. (2000): Ground water potential in a semi-arid region of Andhra Pradesh a geographical information system approach. - Int. J. Remote Sens. 21(9): 1867-1884.

[15] Natarajan, D., John Britto, S., Balaguru, B., Nagamurugan, N., Soosairaj, S. (2004): Identification of Conservation Priority sites using remote sensing and GIS - A case study from Chitteri Hills, Eastern Ghats, Tamil Nadu. - Cur. Sci. 86(9): 1316-1323.

[16] Nayar, M.P., Sastry, A.R.K. (eds.) (1987-90): Red data book of Indian plants. - Botanical Survey of India, Deep Printers, Culcutta. Vol. I, II, III.

[17] Olson, D.M., Dinertein, E., Powell, G.V.N., Wikramanayake, E.D. (2002): Conservation Biology for the biodiversity Crisis. - Conserv. Biol. 16: 1-3.

[18] Prasad, B. (2000): Monitoring of JFM in India: issues and methods. - Ind. Fores. 126: 516-524.

[19] Pressey, P.L., Hager, T.C., Ryan, K.M., Schwarz, J., Wall, S., Ferrier, S., Creaser, P.M. (2000): Using abiotic data for conservation assessments over extensive regions: quantitative methods applied across New South Wales, Australia. - Biol. Conserv. 96: 55-82.

[20] Ramesh, B.R., Menon, S., Bawa, K.S. (1997): A vegetation based approach to biodiversity gap analysis in the Agasthyamalai region, Western Ghats, India. - Ambio 26: 529-536.

[21] Sankaran, V., Hilaluddin, Bandhyopadhyay, P. (2000): The process of Participatory Mapping for planning for biodiversity conservation. - In: Singh, S., Sastry, A.R.K., Mehta, R., Uppal, V. (eds.) Setting biodiversity priorities for India, 1: 34-41. - World Wide Fund for Nature, India, New Delhi.

[22] Scott, J.M., Csuti, B., Smith, K., Estes, J.E., Caicco, S. (1991): Gap analysis of species richness and vegetation cover: an integrated biodiversity conservation strategy. - In: Kohm, K. (ed.) Balancing on the brink of extinction: the endangered species act and lessons for the future. - Island Press, Washington, D.C. pp. 282-297.

[23] Singh, S., Taneja, B. (2000): Prioritisation for biodiversity conservation values and criteria. - In: Singh, S., Sastry, A.R.K., Mehta, R., Uppal, V. (eds.) Setting biodiversity priorities for India, 1: 28-41. - World Wide Fund for Nature, India. New Delhi.

[24] Smiet, A.C. (1992): Forest ecology on Java: Human impact and vegetation on Mountain Forest. - J. Trop. Ecol. 8: 129-152.

[25] Smith, P.G.R, Theberge, J.B. (1986): A review of criteria for evaluation natural areas. Environ. Manag. 10: 715-734.

[26] Smith, P.G.R, Theberge, J.B. (1987): Evaluating natural areas using multiple criteria: theory and practice. - Environ. Manag. 11: 447-460.

[27] Soosairaj, S., John Britto, S., Balaguru, B., Nagamurugan, N., Natarajan, D. (2004): Mapping forest types of Pacchaimalai Hills, Eastern Ghats, India using Remote sensing and GIS. - Ecol. Environ. Conserv. 10(2): 131-135.

[28] Stoms, D.M. (2000): GAP management status and regional indicators of threats to biodiversity. - Landscape Ecol. 15: 21-33.

[29] Strittholt, J.R., Dellasala, D.A. (2001): Importance of Roadless areas in biodiversity conservation in forested ecosystems: case study of the Klamath - Siskiyou ecoregion of the United States. - Conserv. Biol. 15: 1742-1754.

[30] Tilman, D., Knops, J., Wedin, D., Reich, P., Ritchie, M., Siemann, E. (1997): The influence of functional diversity and composition on ecosystem processes. - Sci. 277: $1300-1302$.

[31] Trivedi, P.R. (2001): Global biodiversity. - Authors Press, Delhi.

[32] Udayalakshmi, V., Dutt, C.B.S. (1998): Microlevel planning and sustainable forestry through GIS. - Cur. Sci. 75: 245-255.

[33] Williams, P.H., Margules, C.R., Hilbert, D.W. (2002): Data requirements and data sources for biodiversity priority area selection. - J. Biosci. 27: 327-338. 